Témoigner Témoigner. Entre histoire et mémoire

Getuigen Revue pluridisciplinaire de la Fondation Auschwitz

$122 \mid 2016$

Révisionisme et négationisme

Negationisme en slachtofferconcurrentie

Négationnisme et concurrence des victimes

Negationism and competitive victimhoods

Valentina Pisanty

Traducteur : Gorik de Henau

\title{
OpenEdition
}

Journals

Édition électronique

URL : https://journals.openedition.org/temoigner/4390

DOI : $10.4000 /$ temoigner.4390

ISSN : 2506-6390

Éditeur :

Éditions du Centre d'études et de documentation Mémoire d'Auschwitz, Éditions Kimé

Édition imprimée

Date de publication : 2 mai 2016

Pagination : 87-98

ISSN : 2031-4183

Référence électronique

Valentina Pisanty, «Negationisme en slachtofferconcurrentie», Témoigner. Entre histoire et mémoire

[Online], 122 | 2016, Online op 30 septembre 2021, geraadpleegd op 04 janvier 2022. URL: http:// journals.openedition.org/temoigner/4390 ; DOI: https://doi.org/10.4000/temoigner.4390

Tous droits réservés 


\section{Negationisme en slachtofferconcurrentie}

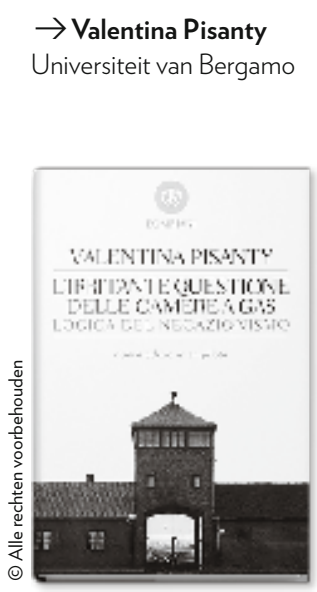

(1) Voor een nauwkeurig onderzoek van de retorische strategieën van de negationisten raad ik aan: Vidal-Naquet 1987; Fresco 1980; Pressac 1993;

Pisanty 1998.

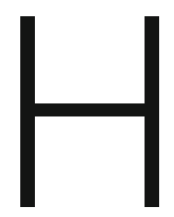

et negationisme is een retorisch hulpmiddel met een interne logica, een repertoire van terugkerende motieven en een arsenaal aan argumentatietechnieken, met als doel twijfel te zaaien over het waargebeurde karakter van de Jodenvervolging door de nazi's. Je kunt het analyseren als een bijzonder semiotisch object, door de interpretatieve en discursieve strategieën te ontleden waarvan de 'papieren Eichmanns' - de benaming is van Pierre Vidal-Naquet (1987) - zich bedienen om vol te houden dat de Holocaust een uitvinding is van de zionistische propaganda. ${ }^{1}$ Maar een retorisch hulpmiddel opereert niet in een vacuüm. Het zou niet bestaan, tenzij dan in het hoofd en de uitlatingen van een beperkt aantal personen, zonder ontvankelijke toehoorders, zonder een cultureel systeem dat erop is gericht het te ontvangen, al is het dan maar om het af te keuren of te censureren. Daaruit volgt dat het negationisme iemand nodig heeft die er het functioneren van verzekert, door de communicatiekanalen op te starten die het doeltreffend maken. Als men het bij wijze van hypothese zou ontmijnen, zoals McLuhan naar aanleiding van de terreur in Italië in de jaren zeventig had voorgesteld (1978), zou het verdwijnen als sociaal fenomeen, of het zou minstens weer worden verbannen naar de semiprivékanalen van zijn actieve aanhangers.

In dit artikel zal ik mijn aandacht richten op bepaalde culturele ontwikkelingen vanaf het moment dat het negationisme zijn intrede deed op het mediatoneel, namelijk in de winter van 1978-1979, toen in Frankrijk de affaire-Faurisson losbarstte. Waarom zochten de negationisten precies dan de publiciteit, na dertig jaar ondergrondse activiteit? Hoe werden ze in de media voorgesteld, welke plaats veroverden ze in het openbare debat en hoe slaagden ze erin hun publiek te verbreden? Want tot dan toe was het negationisme in cultureel opzicht een marginaal fenomeen geweest, dat hoogstens een paar nostalgici van het nazifascisme had weten te boeien.

Ik ga uit van volgende hypothese: de negationisten begonnen een breder publiek te veroveren toen ze leerden hun voordeel te halen uit de toenmalige polemieken over de herinnering in Europa en de Verenigde Staten. Er ontstond namelijk een spanning tussen twee herinneringsdiscours: het ene promootte de zogenaamd unieke en onvergelijkelijke aard van de Holocaust, terwijl het andere een concurrenende visie onderschreef, waarin dat primaat precies ter discussie kwam te staan. 
Negationisme en slachtofferconcurrentie (vervolg)

Dat laatste discours ontleende haar narratieve structuur aan het model waarmee de geschiedenis van de Joodse genocide een plaats had weten te veroveren in het collectief bewustzijn. Door het heersende klimaat van intens geharrewar werd het voor de negationisten makkelijker om hun stelling onder de aandacht van de media te brengen en te laten doorsijpelen in het herinneringsdebat. Het negationistische vertoog vormde zo een onderdeel van een complexer raderwerk, waarin de herinnering op een patriomoniale manier werd opgevat, als een middel dat in het eigen voordeel kan worden geëxploiteerd.

\section{DE BIG BANG VAN HET GEVAL-FAURISSON}

De data vallen op betekenisvolle wijze samen. De eerste brieven van Faurisson in Le Matin (1.11.1978) en Le Monde (16.12.1978 en 29.12.1978) werden net gepubliceerd tijdens de maand waarin de westerse pers zich opwond over de verdiensten en gebreken van de minitelevisiereeks Holocaust. Deze mediagebeurtenis

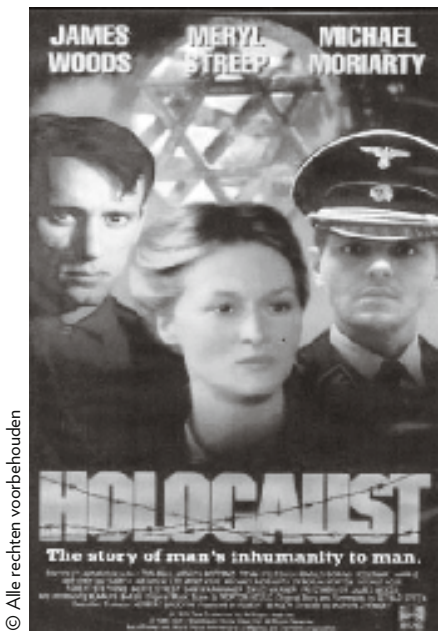
heeft meer dan om het even welke andere bijgedragen tot de collectieve beeldvorming over de Holocaust ${ }^{2}$ en plaatste die in het centrum van de algemene kennis en bewustzijn, na decennia gekenmerkt door een relatieve verdringing of een 'laten bezinken' van het trauma. Het lanceren van die televisiebewerking, die van 16 tot 19 april 1978 door de Amerikaanse tv-zender NBC werd uitgezonden, ging gepaard met geanimeerde discussies. Daarin ging het enerzijds over de historische inhoud van de televisiefilm, namelijk het lot van de Europese Joden en de oorsprong van het nazikwaad. Anderzijds werd scherpgesteld op de manier waarop die kwesties naar het televisiescherm waren vertaald en het ongehoord commerciële karakter daarvan: was het geoorloofd de geschiedenis van de uitroeiing te herleiden tot beproefde narratieve structuren om ze toegankelijker te maken voor een groot publiek? De kritische reacties vielen al snel in twee kampen uiteen. Aan één kant stonden zij die van mening waren dat de Amerikaanse entertainmentindustrie zich met de miniserie op schaamteloze wijze een traumatische ervaring had toegeëigend; volgens hen mocht die alleen worden verteld door wie ‘erbij waren'. Daartegenover stonden zij die vonden dat de reductie tot een schouwspel - met alle bijbehorende gevaren voor bagatellisering - de prijs was die moest worden betaald; zo kon de herinnering aan de volkerenmoord de strikte grenzen van de slachtoffergemeenschap overstijgen en deel gaan uitmaken van het erfgoed van de hele mensheid. De polemiek daarover in Frankrijk zou maanden duren en de oude discussie over de onmogelijkheid om de Holocaust weer te geven laaide opnieuw op. Claude Sarraute vatte een en ander als volgt samen:

(2) 'More information about the Holocaust was imparted to more Americans over those four nights than over all the preceding thirty years', aldus Peter Novick in The Holocaust in American Life (1999, 209).
Waar begint en waar eindigt de zin voor het sacrale? Magje alles zeggen, vereenvoudigen, uitspellen voor de massa's, inclusief het onzegbare? Moet je om doeltreffend te zijn het risico lopen te vulgariseren, en het absolute kwaad en de totale gruwel te bagatelliseren? 
Als je het lot van de Holocaust-martelaars oproept met populaire prentjes, beledig je of eer je hen dan? Heb je in een dergelijk geval het recht om feit en fictie te vermengen? (Sarraute 1978)

Volgens de voorstanders van dergelijke historical fiction, en meer bepaald Sarraute zelf, was de geschiedenisles van Holocaust echt noodzakelijk voor het Amerikaanse publiek, dat blijk had gegeven van een dermate vage kennis over de uitroeiing dat het die soms zelfs minimaliseerde of ontkende. Volgens de journaliste werd haar bekommernis gedeeld door meerdere joodse Amerikanen, onder anderen de rabbijn Marc Tannenbaum (directeur van de afdeling interreligieuze zaken bij de Anti Defamation League en ook deskundige-adviseur van de NBC tijdens de productie van de televisiefilm). Via hem had ze vernomen dat heel wat Amerikanen de Holocaust beschouwden als een obsessie van de joodse gemeenschap, als was het een vervelende vraag om aandacht of, erger nog, chantage ten voordele van de zionistische zaak. Ter ondersteuning van die verklaringen vermeldde Tannenbaum de activiteiten van bepaalde Amerikaanse neonazistische verenigingen (aangevoerd door de Christian Defense League). Toen Holocaust werd uitgezonden hadden die voor de NBC-studio's in Baton Rouge (Louisiana) paaltjes opgesteld met borden waarop de uitroeiing werd ontkend en tijdens de uitzending hadden ze de televisiezender met honderden protesttelefoontjes bestookt (The New York Times 17 april 1978).

Op zich zouden de demonstraties van neonazi's, gezien het beperkte aantal deelnemers, niet veel hebben voorgesteld. En toch, hoe meer ze erop wezen dat de vrees voor een nog levendige antisemitische haat gegrond was, hoe schandaliger ze leken (en dus de moeite waard om het nieuws te halen). De activisten van de Christian Defense League, aangetrokken door de schijnwerpers van de NBC, troepten samen waar ze het meest in het oog vielen van de indrukwekkende publiciteitsmachine die voor het lanceren van de miniserie was georganiseerd. Ze vonden het plezierig de rol van erfgenamen van Dorf en andere televisienazi's te vertolken, maar weigerden tegelijk als antisemieten te worden bestempeld. Het veelvoud aan belangen en de hevige uitvallen die een paar maanden later de zaak-Faurisson zouden kenmerken, waren hier al in de kiem aanwezig. Aan de ene kant had je de producenten en opvoeders; zij waren het eens over een sensationele versie van de genocidegeschiedenis, vol waarschuwingen en lessen met universele, makkelijk te begrijpen waarden. Aan de andere kant stonden de vermanende critici en een aantal invloedrijke getuigen; zij kantten zich tegen het commercieel en retorisch uitbuiten van een levendig en pijnlijk trauma dat nog altijd in het geheugen van de slachtoffers stond gegrift. Tot slot waren er de racisten; zij hadden het gemunt op de herinnering aan een historische misdaad die ontegenzeglijk afschuwelijk was, maar die ze toch trachtten te verdringen om de oude stelling van de Joodse samenzwering weer uit de kast te kunnen halen. Ongetwijfeld is het waar dat het verspreiden van historische kennis kan helpen tegen de verwarring en onwetendheid waarin racisme en antisemitisme gewoonlijk wortel schieten. Maar het is net zo goed waar dat door de sensationele 
Negationisme en slachtofferconcurrentie (vervolg) verpakking van die kennis het exhibitionisme van de ontkenners werd geprikkeld, en ook de nieuwsgierigheid van zij die hun tot dan toe niet al te veel aandacht hadden geschonken.

De negationisten zochten de internationale schijnwerpers niet alleen op via die ene gelegenheid. Enkele dagen later beschouwden de Amerikaanse media het incident al als afgedaan; zij waren vertrouwd met de neveneffecten van de grondwettelijke vrijheid van meningsuiting. De redactie van $L$ 'Express, dan onder leiding van Jean-François Revel, stak de lont in het kruitvat toen ze zes maanden later (28.10-4.11.1978) een interview publiceerde van Philippe Ganier-Raymond met Louis Darquier. Hij was voormalig commissaris-generaal voor Joodse Zaken tijdens het Vichy-bewind, werd in 1947 bij verstek ter dood veroordeeld en verbleef sindsdien officieel in Andalusië. 'In Auschwitz werden alleen de vlooien vergast', verklaarde de verantwoordelijke van de razzia in de Vélodrome d'Hiver. Zoals te verwachten was, brak het schandaal los. Waarom kreeg een onbestrafte en onverbeterlijke crimineel het woord, iemand die op provocerende wijze de stelling van de Joodse samenzwering ondersteunde en het bestaan van de gaskamers ontkende? Want in de actualiteit was er geen enkele aanleiding om opnieuw met hem voor de dag te komen (behalve het directe verband met de Camp Davidakkoorden van 17 september 1978). En waarom uitgerekend op dat ogenblik? Simone Veil, toen minister van Gezondheid en Familiezaken, was zeer kritisch over de primeur van L'Express; ze weet een en ander aan de bredere tendens om de nazimisdaden te relativeren en de Vichy-vergrijpen te vergoelijken. Zij werd gevolgd door Pierre Viansson-Ponté (1978) en de Raad van de Joodse Gemeenschappen in Frankrijk; in een persbericht van 1 november 1978 suggereerden ze dat de uitlatingen van Darquier deel uitmaakten van 'een verontrustende en georkestreerde campagne om van racisme iets alledaags te maken en de gruwel van de volkerenmoord te bagatelliseren'. Revel en Raymond Aron, diens medewerker bij L'Express, verworpen die beschuldigingen heftig; ze verduidelijkten dat ze met het interview juist de bedoeling hadden gehad 'om de schijnwerpers te richten op racisme als een pathologie van het menselijke denken, zoals je dat met een kankergezwel doet' (Aron \& Revel 1978). Diezelfde dag publiceerde Le Matin de eerste brief van Faurisson.

Intussen aarzelden de drie Franse televisiezenders om de rechten van de NBC-miniserie te verwerven, in tegenstelling tot de derde West-Duitse zender. Ook hierop volgden hevige discussies tussen de voor- en tegenstanders van het programmeren van het historische feuilleton in Frankrijk, waarbij vaak naar het geval-Darquier werd verwezen. Simone Veil adviseerde uit te zenden als tegengif tegen de ziekte van het relativisme, waarvan het L'Express-interview volgens haar het duidelijkste symptoom was. Maar eerste minister Raymond Barre waarschuwde de directeuren van de zenders tegen de valkuilen van de sensatiezucht en spoorde hen aan om deze gevoelige thema's met de grootste omzichtigheid te behandelen. Die behoedzaamheid werd door sommigen geïnterpreteerd als weigerachtigheid om het openbare debat aan te gaan over een van de schandelijkste hoofdstukken uit de recente Franse geschiedenis, dat was begraven onder de absolutie die het Franse 
verzet zichzelf had verleend. Anderen schreven haar dan weer toe aan onbezonnen antiamerikanisme of misschien een verdoken vorm van antizionisme. Was het juist om de Amerikaanse televisiefilm uit te zenden? Was het juist om het interview met Darquier te publiceren? Aan welke van beide vormen van bagatellisering (sensatiezucht of relativisme) mocht je zeker niet toegeven? Of was het beter geweest een einde te maken aan die vragen en het woord uitsluitend aan de overlevenden te laten, zoals Elie Wiesel al had gesuggereerd in zijn beroemde bijtende kritiek in The New York Times van 16 april 1978? Het voorbehoud viel weg op 30 november 1978, toen Antenne 2 aankondigde dat het de rechten voor Holocaust wilde verwerven. Als om de morele urgentie van die beslissing aan te tonen, publiceerde Le Monde twee weken later de tweede brief van Faurisson.

\section{ONTKENNEN, BAGATELLISEREN, HEILIG VERKLAREN}

Je moet de kroniek van de gebeurtenissen doornemen om daarin een eventuele structuur te ontdekken, een retorisch raderwerk, een terugkerende dynamiek. Het negationisme sluit aan bij de kronkels van een breder debat over de gebruiken en misbruiken van de herinnering. ${ }^{3}$ Net op het ogenblik dat die het voorwerp wordt van enorme economische en politieke investeringen, nog versterkt door tegenstrijdige belangen in het heden, ontstaan concurrentiemechanismen tussen personen die er om de meest uiteenlopende redenen controle over willen verwerven. Iedereen beschuldigt de ander ervan de herinnering te bagatelliseren, anders gezegd haar te onderwerpen aan zijn eigen specifieke doelen, of die nu commercieel of ideologisch zijn - en het doet er weinig toe of die beschuldiging terecht is, gemeend is ze altijd. En omdat beschuldigingen van bagatellisering vaak gepaard gaan met een verbod op heiligverklaring, wordt de omstreden nagedachtenis al snel met een barrière afgeschermd, in de vorm van taboes en voorschriften waarmee de toegang ertoe wordt gecontroleerd. Zo ontstaat een categorie mensen met het gezag om het vertoog van anderen grondig te onderzoeken en te beslissen welk geoorloofd is en welk niet, welk als gepast kan gelden en welk net moeten worden verworpen als een onwettig beroep op de geschiedenis. Om die rol van 'bewaker' van de nagedachtenis vechten verenigingen van voormalige gedeporteerden, vooraanstaande figuren, culturele instellingen en gouvernementele organisaties. Ze zijn het vaak onderling oneens en willen de herinnering beschermen tegen de aanvallen van zij die er om uiteenlopende redenen belang bij hebben om haar te plunderen, uit te buiten, te misbruiken of zelfs te doen verdwijnen. De negationisten slopen ongemerkt binnen in die scheldtirades om zich zo een weg te banen in de media. Door de vele veto's en veroordelingen over en weer werd het terrein voorbereid voor het salvo van verklaringen waarmee Faurisson de rol van absoluut provocateur verwierf en waarmee hij de verontwaardiging, angst en rancune kanaliseerde die door de polemieken van de voorgaande dagen waren opgeworpen. De negationistische stellingen werden opgenomen in de vanaf dan vertrouwde categorie 'Holocaustcontroverses' en kregen een plaats in de journalistieke palimpsesten, altijd in naam van het aanvechtbare
(3) Over de polemisch gelijklopende verbanden tussen ontkenning, bagatellisering en heiligverklaring heb ik me al gebogen in een essay uit 2012 (Pisanty 2012). 
Negationisme en slachtofferconcurrentie (vervolg) principe dat je een ziekte moet behandelen door ze openbaar te maken. Maar door het fenomeen te tonen (en ook de onvermijdelijke protesten die erop volgen), wordt dat niet overwonnen, maar wordt het juist nog groter; het wordt onderdeel van een breder retorisch systeem en net omdat je het wilt uitbannen, krijgt het paradoxaal genoeg legitimiteit. Het negationisme laaft zich aan de verontwaardiging die het opwekt, vooral als die laatste zich met de officiële kleuren van de censuur tooit. Zelfs de meest aangrijpende aanklachten, zoals die van 34 Franse historici in $L e$ Monde van 21 februari 1979, sorteren het ongewenste effect dat de polemiek daardoor naar het probleem van de vrijheid van meningsuiting verschuift. 'Over het bestaan van de gaskamers is geen discussie en er mag er ook geen zijn': via die ongelukkige formulering verwarden de bewuste historici een meer dan legitieme historiografische weigering om de negationisten toe te laten tot de mogelijke gesprekspartners (het heeft geen zin te discussiëren met charlatans) met een moreel aanvechtbaar verbod (niemand mag het wagen de uitroeiing in twijfel te trekken), waardoor dan weer nieuwe controversen en andere eisen werden veroorzaakt. Door dit delicate dilemma gingen nieuwe stemmen op: moet je het crapuul knevelen? Wat is onuitstaanbaarder: dat iemand de gaskamers ontkent of dat iemand anders hem dat belet? En waarom leiden andere historische ontkenningen niet tot een dergelijke stroom van protest? Of hebben we hier misschien te maken met de zoveelste uiting van het 'Joodse particularisme' waarvan velen stilletjes spreken, maar waarover maar weinigen het openlijk durven hebben, althans in een officiële context?

\section{VERGELIJKINGEN}

Holocaustontkenning is niet de enige vorm van negationisme. Ook andere historische misdaden als de Armeense volkerenmoord (1915-1916; zie Hovannisian 1999), het bloedbad in Nanking (1937) en het bloedbad in Katyń (1941) werden onmiddellijk in de doofpot gestopt en vervolgens systematisch en hardnekkig ontkend. Het meest besproken geval, toch in het Westen, is de ontkenning van de Armeense volkerenmoord, waarmee de Turkse nationale identiteit rotsvast is verbonden. Sinds eind jaren zestig hebben auteurs als Kamuran Gürün, Stanford Shaw, Justin McCarthy en Bernard Lewis de regering in Ankara gesteund met artikelen en essays. Daarin bekrachtigen ze de officiële stelling dat de evacuatie van duizenden Armeniërs weg van de Anatolische hoogvlakte niet het gevolg zou zijn geweest van een uitgewerkt vernietigingsplan vanwege de regering van de Jonge Turken, maar veeleer van de klaarblijkelijke noodzaak de Armeniërs opnieuw te vestigen wegens hun rebellerende terroristische activiteiten. Het is correct dat bepaalde vluchtelingen tijdens het traject naar Syrië en Mesopotamië zouden zijn omgekomen door ziekte en ontbering, maar het merendeel zou de verplaatsing hebben overleefd en elders een nieuw en welvarend bestaan hebben opgebouwd.

De gelijkenissen tussen die argumenten en methode met wat de Holocaustontkenners beweren, springen in het oog. Zo bijvoorbeeld de drastische verlaging van het aantal slachtoffers, het loochenen van het uitroeiingsplan, het ongeldig verkla- 
ren van de getuigenissen en de documenten ten laste, en de toevlucht tot samenzweerdersstellingen om het voortbestaan van de 'genocidemythe' te verklaren. De belangrijkste verschillen slaan dan weer op de machtsstructuur en -dynamiek van de negationistische strategie. Als het de staat is die ontkent, en niet geïsoleerde groepjes fanatici, dan wordt de herinnering gekortwiekt via censuur, gedwongen verdringing en de voortdurende herhaling van waarheden die als onweerlegbaar worden voorgesteld. De rollen van wie ontkent en wie heilig verklaart (de autoriteit die bepaalt wat je wel en niet mag zeggen) vallen samen, en de bagatellisering (die hier doorgaans neigt tot minimaliseren en relativeren) dient om het hegemonische verhaal te ondersteunen. De drie tandwielen van dit raderwerk worden hier aangedreven door één enkele wil, in tegenstelling tot de Holocaustontkenning, die zich polemisch opstelt (hoewel solidair vanuit systemisch oogpunt) tegenover andere retorische strategieën die zijn gericht op controle van de nagedachtenis.

Om in te gaan tegen het staatsnegationisme volstaat het niet de ontkende gebeurtenis met documenten te bewijzen, zoals je zou doen bij een universele rechtbank. Bij afwezigheid van een gewillig gehoor valt elke historische reconstructie in het luchtledige. Daarom heeft wie de muur van stilte wil doorbreken een politieke en culturele context nodig waarin zijn of haar verzoek ontvankelijk is. Maar men moet er ook in slagen om de alternatieve herinnering samen te ballen in een communicatief en boeiend formaat, dat met andere woorden user-friendly en doeltreffend is in die specifieke context. Het is een vorm van banalisering die eigenlijk gericht is op spektakel, maar die onontbeerlijk is om de verwarde herinnering aan de verdrongen gebeurtenissen om te smeden tot een krachtig en strak verhaal dat stand kan houden tegen de historiografie van het regime.

En dat gebeurde op 24 april 1965, naar aanleiding van de vijftigste verjaardag van de eerste arrestaties onder de Armeense elite van Constantinopel. In Jerevan, de hoofdstad van de Armeense Democratische Republiek (toen deel van de Sovjet-Unie), kwamen duizenden manifestanten samen om te eisen dat het Kremlin de volkerenmoord erkende. De demonstraties breidden zich uit naar de hele wereld, inclusief de Verenigde Staten, waar dankzij de vernieuwde interesse heel wat verschillende initiatieven het licht zagen. We citeren uit dit hoofdartikel in The New York Times (24 april 1965), waarin de Armeense gemeenschap enerzijds een hand werd aangereikt (en tot vergeving werd aangespoord) en ze anderzijds het advies kreeg de twee bloedbaden niet te vergelijken:

Armenians do in fact compare the event to the Hitlerite genocide of the Jews. The numbers massacred by the Turks will never be known. Armenian estimates running as high as 2,000,000. The English historian H. A. L. Fisher sets the figure at 1,000,000. It is terrible enough, although the comparison with Hitler's genocide is not quite accurate. Hitler exterminated Jews simply on racist grounds; in the Turkish extermination of the Armenians, whom they considered a threat to the Ottoman Empire, there was indeed an element of racism, but the primary factor was nationalism. And many Turks also lost their lives in the holocaust. 


\section{DOSSIER}

Negationisme en slachtofferconcurrentie (vervolg)
Wat kunnen we afleiden uit die korte reconstructie? Eerst en vooral dat, om gehoor te vinden bij de internationale media, de Armeense gemeenschap in Amerika haar trauma in het vocabulaire van de Joodse genocide vertaalde. In de geschiedenis van de Holocaust - die in 1965, na het proces-Eichmann, vaste voet aan de grond kreeg in het collectief bewustzijn - vond ze een steun, een model, een begrijpelijk schema waarmee de feiten uit 1915 retrospectief konden worden geïnterpreteerd. Door de vergelijking met dit model ontstond een levendige indruk, en in die vorm begon de Armeense genocide door te dringen in de algemene kennis; de facto kregen de daders van het bloedbad de rol van nazivoorlopers (wat trouwens door Hitler zelf werd toegegeven). Het ging zover dat de Turkse regering sinds de jaren zeventig, omdat de traditionele censuurinstrumenten ontoereikend bleken, haar inspanningen opdreef en de met het regime bevriende academici betrok bij een negationistische campagne die tijdens de volgende decennia steeds zwaarwichtiger en technischer werd. Ook opvallend was de pietluttige reactie van The New York Times, die per se de verschillen tussen de twee genocides wilde duidelijk maken om elke mogelijke gelijkschakeling te vermijden. De toon was verzorgd, maar de boodschap was duidelijk: laten we alstublieft niet bagatelliseren, Hitlers misdaden zijn uniek en met niets te vergelijken.

In het journalistieke vertoog raken de nuances vaak gaandeweg ondergesneeuwd en net zoals vergelijking vaak gelijkschakeling wordt, kan de omgekeerde beweging, die van het benadrukken van verschillen, op haar beurt de allures van een waardeoordeel krijgen: als $\mathrm{x}$ verschilt van $\mathrm{y}$, dan volgt daaruit dat $\mathrm{x}$ meer $\mathrm{z}$ is dan y. Er ontstaat een soort hitparade van bloedbaden, alsof een op nationalistische gronden uitgevoerd bloedbad minder erg - beter te verdedigen of op zijn minst gewoner - was dan een uitroeiing om louter racistische beweegredenen. Het is een stelling waarover je langdurig een (zinloze) discussie kunt voeren, maar waardoor de slachtoffers van het bewuste geweld het gevoel zouden kunnen krijgen dat er een onzinnige rangorde van leed bestaat: onze genocide is erger dan die van jullie, het onrecht (zelfs het allerergste) dat jullie is aangedaan is niet van dezelfde aard als dat van ons.

\section{CONCURRENTIE ONDER DE SLACHTOFFERS}

Zo werd de kiem zichtbaar van wat Jean-Michel Chaumont (2002) de 'concurrentie onder de slachtoffers' noemt - een perverse rivaliteit tussen de klagende en de aanklagende nagedachtenis, die elkaar de 'palm van het leed' betwisten - en waarvoor de Holocaust, naarmate die zich opwierp als de sleutelgebeurtenis in de twintigste-eeuwse geschiedenis, gold als het vergelijkingspunt. Zij die de stelling van het uitzonderlijke karakter van de Holocaust aanvochten, wilden vaak de Joden op polemische wijze het 'geprivilegieerde' statuut van absolute slachtoffers ontzeggen en eisten voor hun eigen referentiegroep een vergelijkbare eretitel op. En omgekeerd maakten de meest onvermoeibare verdedigers van de stelling van het absolute slachtofferschap aanspraak op het superieure lijden van de Joden onder het nazisme; 
ze brandmerkten elke vergelijking met andere vervolgingen als heiligschennende bagatellisering, waardoor hen werd verweten andere slachtoffers uit te sluiten.

Volgde een stroom polemieken die een sneeuwbaleffect hadden tijdens de jaren tachtig, meteen na het succes van Holocaust; alle hadden ze betrekking op het vermeende uitzonderlijke karakter van de Joodse volkerenmoord.

To claim that the holocaust was unique can only imply that attempts to annihilate other national or cultural groups are not to be considered genocide, thus diminishing the gravity and moral implications of any genocide anywhere, any time. It also implies that the Jews have a monopoly on genocide, that no matter what misfortune befalls another people, it cannot be as serious or even in the same category as the Holocaust. (Papazian 1984)

Zo reageert Pierre Papazian zich af, op een manier die stellig niets met negationisme te maken heeft, maar waardoor hij zout in de wonden strooit; hij verwijt de Joden, alsof die een compacte categorie vormden, dat ze hun eigen genocide heilig verklaren ten nadele van andermans genocides. Waarom ziet hij een dergelijk vergrijp in het feit dat de Joodse genocide geldt als de absoluut meest traumatische gebeurtenis in de menselijke geschiedenis? Omdat door die voorrang de tragedies van anderen bij wijze van contrast worden geminimaliseerd. Maar als de Holocaust wordt beschouwd als een 'absoluut unieke' gebeurtenis die losstaat van elke historische reeks en bijgevolg met niets te vergelijken valt, waarom zouden andere bloedbaden er dan aan moeten worden afgemeten en daar de nadelen van ondervinden? Dit is de kern van het probleem: het oordeel van onvergelijkelijkheid staat naast het feit dat de herinnering aan de Holocaust meer en meer het paradigma wordt van alle andere collectieve herinneringen. In het openbare debat is de Holocaust tegelijk uitzondering en regel, een paradoxaal prototype dat naast zich geen andere gevallen duldt (zie ook Giglioli 2014).

Laten we even stilstaan bij deze aporie, die tot zoveel controverse leidt. Sinds de Holocaust is gepromoveerd tot uitzonderlijke gebeurtenis in de geschiedenis van de mensheid is elke andere gebeurtenis beginnen te lijken op (of wordt ze voorgesteld als) een afleiding, een benadering bij verstek, een gedeeltelijke kopie van die jammerlijk voorbeeldige gebeurtenis. Van de Nakba tot de Libanese burgeroorlog, van ex-Joegoslavië tot $9 / 11$ is er de laatste tientallen jaren geen internationaal conflict dat niet werd gefilterd door het vocabulaire van de Holocaust, met alle overtrokken vergelijkingen en bagatelliseringseffecten van dien. De gelijkschakeling (die in min of meerdere mate aanleiding geeft tot bagatellisering) heeft trouwens golven van verontwaardiging tot gevolg die de media maar wat graag versterken. Het principe van het uniek-zijn wordt heftig verdedigd, terwijl zij die banaliseren de verdenking op zich laden van antisemitisme en heiligschennis van de herinnering. Dit gebeurt soms met historische argumenten, zoals in het Armeense artikel in The New York Times, soms met dogmatische stellingnamen over de absolute onmogelijkheid een gebeurtenis die 'de geschiedenis overstijgt' met iets anders te vergelijken. Al even gericht zijn de intolerante reacties van hun tegenstanders, die de bewakers van het 
Negationisme en slachtofferconcurrentie (vervolg) geheugen (inderhaast gelijkgeschakeld met de internationale Joodse gemeenschap) ervan beschuldigen de Holocaust heilig te verklaren met het oog op hun eigen, specifieke ideologische doeleinden (bijvoorbeeld het monopoliseren van de herinnering ten voordele van de zionistische zaak). Een escalatie wordt onvermijdelijk.

Door die storm krijgen de negationisten diverse opties. Om te beginnen gaan ze tactische allianties aan met zij die bagatelliseren, waarbij ze mikken op afkeer van elk misbruik van het geheugen in de zin van heiligverklaring. Laten we, om te begrijpen hoe je vertrekkend van gelijksoortige overwegingen (meer bepaald het hekelen van de Joodse neiging om de herinnering als heilig te beschouwen) kunt afglijden naar ideologische instemming met het negationistische vertoog - dat Thion voorstelt als een moedig uitdagen van historiografische taboes en het onverdraagzame dictaat van het academische establishment - deze passage van Serge Thion lezen en ze vergelijken met het hoger vermelde citaat van Pierre Papazian:

Niemand zal ontkennen dat er een soort aarzeling of zelfs censuur bestaat tegenover elke uitspraak over de Joden of het zionisme of Israël als die niet eerst op de een of andere manier is goedgekeurd. Om er gehoor aan te geven moet je eerst weten, zoals dat dan heet, wie aan het woord is. Zonder een gepaste bekrachtiging of een teken van legitimering wordt elke uitspraak daaromtrent de grond ingeboord of argwanend bekeken. (Thion 1980)

In dat opzicht is het iconoclasme van de negationistische stellingen op zichzelf al een goede reden om aandacht te besteden aan Faurisson (om je af te vragen 'of er ook maar het geringste argument is om het probleem van de gaskamers te bespreken in termen van historische feiten') - los van de waarde van zijn betoog, waarover Thion zich liever niet uitspreekt.

Een nog dubbelzinniger vorm van collaboratie pleegde Ernst Nolte. In zijn poging om de nazimisdaden gelijk te schakelen met de misdaden van de Sovjet-Unie wijdde hij een tussenhoofdstuk van Streitpunkte (Nolte 1993) aan het 'perspectief van het radicale revisionisme', dat wil zeggen het negationisme; hij beweerde dat 'de technische deskundigen in de discussies [over het bestaan van de gaskamers] het laatste woord nog niet hebben gezegd'. We stellen vast dat Nolte nergens zo ver gaat dat hij expliciet de negationistische stelling bijtreedt. In het eerste hoofdstuk van zijn boek lijkt hij die zelfs van de hand te wijzen: 'Er kan geen gegronde twijfel bestaan over het echt gebeurd-zijn van de uitroeiingspolitiek tegen het Duitse en Europese Jodendom.' Maar een paar pagina's verder zet hij de deur weer op een kier voor de twijfel, door legitimiteit te verlenen aan auteurs als Stäglich, Roques, Leuchter en Mattogno. Hij heeft lof voor hun wetenschappelijke formulering, goede trouw en solide bewijsvoering, en moedigt de lezer aan om hen serieus te nemen, al was het maar uit naam van het principe van de vrijheid van meningsuiting. Door dergelijke openingen lijkt het wel of er sprake is van een stilzwijgend en niet noodzakelijk bewust rollenspel tussen Nolte en de negationisten. Noltes rol zou zich beperken tot het geloofwaardig maken van de negationisten en het twijfel zaaien over het 
daadwerkelijke karakter van de uitroeiing, zonder evenwel zo ver te gaan als het ontkennen van de gaskamers (het 'enige punt van verschil' tussen de nazimisdaden en de misdaden van de Sovjet-Unie). De negationisten nemen dan weer de vuile taak op zich van de onvoorwaardelijke ontkenning, waardoor - als die ingang zou vinden - in de algemene kennis de belangrijkste hinderpaal zou verdwijnen om de nazi- en de Sovjetmisdaden volledig gelijk te schakelen. Maar niet zij die bagatelliseren, alles bij elkaar veeleer voorzichtige en bedachtzame lieden, duwen de radicale negationisten in het middelpunt van de mediabelangstelling. Paradoxaal genoeg wordt de machine van de ontkenning vooral gevoed door de opzienbarendste banvloeken en de strengste censuur. Of het nu gaat om de hoger vermelde verklaring van de 34 historici tegen Faurisson of om het uitvaardigen van specifieke nagedachteniswetten, de overtreders worden door de tot heiligverklaring aanzettende verboden in een ondergrondse zone van de algemene kennis gedrongen. Daar sluit een cultuur haar monsters op, maar doet ze niet verdwijnen, want ze worden er juist het voorwerp van morbide aandacht. En in het kielzog van elke nieuwe toepassing van de wet-Gayssot [een Franse wet uit 1990 die Holocaustontkenning verbiedt] of gelijksoortige wetten ontstaat de facto de gebruikelijke reeks polemieken, petities en open brieven waarmee de negationisten de media halen.

'Ze straffen zou er alleen voor zorgen dat ze nog talrijker worden', zo waarschuwde in 1987 Pierre Vidal-Naquet (1987), die had voorzien dat de verdachten dankzij de toepassing van een antinegationistische wet plotseling weer in de belangstelling zouden staan. Door te stigmatiseren ontstaan contrasterende identiteiten; en daarom is het wetten maken tegen het negationisme als zodanig - en niet tegen andere vergrijpen waaraan het zich soms ook bezondigt - de grootste erkenning die je kunt schenken aan zij die hun antisemitisme vermommen met hooggestemde democratische principes.

Het is onvoorzichtig om die mechanismen in de hand te werken. Volgens Vidal-Naquet betekent niet met de negationisten spreken ook dat je niet tegen hen spreekt, hen niet kiest als directe tegenstrevers. Wel integendeel, spreken over de negationisten betekent dat je hen van een ruime afstand observeert, kijkt hoe ze zich gedragen, begrijpt hoe ze binnendringen in het meest complexe historische, politieke en culturele raderwerk. Dat komt erop neer dat je het fenomeen ontheiligt om het te ontdoen van elke diabolische charme en elke tegen het bestel gerichte aantrekkingskracht. Het betekent ook dat je er, voorbij het sektarisme, de platheid van laat zien, dat je je tegelijk inzet opdat de ontkenningsstrategieën in het collectief bewustzijn beperkt blijven tot overbekende trucjes waaraan alleen een uitzonderlijk naïeve lezer zich zou kunnen laten vangen.

Vertaling: Gorik de Henau 
Negationisme en slachtofferconcurrentie (vervolg)

\section{BIBLIOGRAFIE}

- Raymond Aron \& Jean-François Revel, 'Une lettre de MM. Raymond Aron et Jean-François Revel', Le Monde, 1 november 1978.

- Esther Benbassa, La souffrance comme identité, Parijs: Fayard, 2007.

- Jean-Michel Chaumont, La concurrence des victimes, Parijs: La Découverte, 2002.

- Dan Cohn-Sherbok (red.), Holocaust Theology. A Reader, New York: New York University Press, 2002.

- Marcello Flores, Simo Levis Sullam, Marie-Anne Matard-Bonucci \& Enzo Traverso (red.), Storia della Shoah in Italia. Vicende, memorie, rappresentazioni, Torino: UTET, 2010.

- Nadine Fresco, 'Les redresseurs de morts', Les Temps Modernes 407, 1980.

- Daniele Giglioli, Critica della vittima, Roma: Nottetempo, 2014.

- Maurice Halbwachs, La mémoire collective, Parijs: PUF, 1950.

- Richard G. Hovanisian, Remembrance and Denial: The Case of the Armenian Genocide, Detroit: Wayne State University Press, 1999.

- Herbert M. McLuhan, interview in Corriere della sera, 23 maart 1978.

- Ernst Nolte, Streitpunkte, Berlin: Propyläen, 1993.

- Peter Novick, The Holocaust in American Life, Boston: Houghton Mifflin, 1999.

- Pierre Papazian, 'A Unique Uniqueness?', Midstream 30(4), 1980, 14-18.

- 'Pickets at TV Studio Protest "Holocaust”', The New York Times, 17 april 1978.

- Valentina Pisanty, L'irritante questione delle camere a gas: logica del negazionismo, Milaan: Bompiani, 1998.

- Valentina Pisanty, Abusi di memoria, Milaan: Bruno Mondadori, 2012.

- Pier Paolo Poggio, Nazismo e revisionismo storico, Rome: Manifestolibri, 1997.

- Jean-Claude Pressac, Les crématoires d'Auschwitz. La machinerie du meurtre de masse, Parijs: CNRS, 1993.

- Gian Enrico Rusconi (red.), Un passato che non passa, Turijn: Einaudi, 1987.

- Claude Sarraute, 'Les simplifications nécessaires', Le Monde, 2 mei 1978.

- Serge Thion, Vérité historique ou vérité politique, Parijs: La Vieille Taupe, 1980.

- Tzvetan Todorov, Les abus de la mémoire, Parijs: Arléa, 1995.

- Enzo Traverso, Il passato. Istruzioni per l'uso, Verona: Ombre Corte, 2006.

- Christoph Türcke, Gewalt und Tabu. Philosophische Grenzgänge, Lüneburg: Dietrich zu Klamplen Verlag, 1987.

- Pierre Vidal-Naquet, Les assassins de la mémoire, Parijs: La Découverte, 1987.

- Pierre Viansson-Ponté, 'Le mensonge', Le Monde, 31 oktober 1978.

- Elie Wiesel, 'Trivializing the Holocaust', The New York Times, 16 april 1978. 